\title{
Gästredaktörens förord
}

PA FRAMSIDAN TILL detta nummer av lambda nordica ser vi en hund som intensivt betraktar skyltningen till "Katternas månad" i numera nedlagda Kvinnobokhandeln Medusa i Stockholm. Bilden är humoristisk därför att den erinrar om kulturella föreställningar om motsättningar mellan hund och katt, men humorn ligger även i den mänskliga betraktarens förförståelse av vad djur respektive människor kan se och uppfatta. Vi ser en "verklig" materiell hund som tittar på "overkliga" kulturella representationer av katter - kulturella representationer som inom en humanistisk, antropocentrisk förståelse av människa och djur endast ses som möjliga att avkodas av människor.

Men bilden är även intresseväckande då den förmedlar en förstålse av vad som kan anses vara viktigt och relevant i människors respektive djurs värld. Hunden - som för övrigt var en neapolitansk mastiff och hette Gina - är helt fokuserad på representationerna av katter på bilden, medan den mänskliga betraktarens öga kanske finner större intresse i den tavla med motiv regnbågsflagga som också syns innanför glasrutan. Är denna västerländskt kulturella symbol för homosexuell emancipation och stolthet betydelselös och ointressant för Gina? Och vad betyder det för den mänskliga blicken på "djuret" när normer om sexualitet och kön förs in i förståelsen av djurets värld och i relationen människa-djur?

Dessa är några frågeställningar som motiverar detta specialnummer av lambda nordica med tema "Djur". Som en ingång till fältet 
fungerar Helena Pedersens essä Queerforskning och djurstudier: kreativa korsbefruktningar. Här konstateras att ett grundläggande gemensamt tema för kritik inom queer- och djurstudieforskningen är de kategorier som djur och människor inordnas i. Med nedslag i forskning om naturfilmer, djurforskning, köttproduktion, reproduktion och husdjur samt med skönlitterära exempel visar Pedersen att en korsbefruktning mellan djurstudier och queerstudier har potential att radikalisera och skapa utrymme för nytänkande inom båda fälten.

Den första artikeln, Biologins paradox: föränderliga kön och rigida normer, är skriven av Malin Ah-King. Här problematiseras de heteronormativa utgångspunkter som präglar studiet av djur inom biologisk forskning, vilket innebär att sociala normer är verksamma när djurs beteenden tolkas. Samtidigt, menar Ah-King, påverkar synen på vad som är "naturligt" samhällsdebatt och politiskt klimat. Men att göra det som är "vanligt" inom biologin till norm är att blunda för den enorma variation avseende kön och sexuella beteenden som finns. Efter en systematisk genomgång av olika heteronormativa antaganden inom den biologiska forskningen formulerar så Ah-King slutligen ett förslag på hur en icke-normativ förståelse av kön och sexualitet inom detta fält kan uppnås.

Den andra artikeln, Mellan metafor och litterär materialisering: heteronormer och djurblivande i Monika Fagerholms novell "Patricia Kanin” är skriven av mig själv. Här är den grundläggande tanken att "djur" och "människa" inte är separata kategorier utan ett kontinuum, där positionen är föränderlig och kan ses som ett medlemskap i "människoklubben" respektive "djurklubben". Dessa medlemskap är normativt strukturerade, och avseende djurblivandet i "Patricia Kanin” är det särskilt heteronormen som är verksam, men även normer kring ålder och etnicitet. I analysen fokuseras särskilt hur Patricias förvandling till Kanin inrangeras i en litterär tradition, 
samt även hur denna transformation kan förstås som en glidning mellan metafor och litterär materialisering, mellan anpassning och motstånd.

Den tredje artikeln, Transgenres and the plane of language, species, and evolution, är skriven av Jami Weinstein, vilken hävdar att genusoch queerforskning har hamnat i en teoretisk återvändsgränd. Detta beror på att debatten om distinktionen mellan "sex" och "gender" ständigt återupprättar humanismens logik, enligt vilken biologiskt kön knyts till föreställningar om djur och natur, medan genus ses som specifikt mänskligt. För att komma ut ur denna återvändsgränd föreslår Weinstein begreppet "transgenre" som ett sätt att analysera kön och genus inom en posthumanistisk kontext, vilket innebär att det maktfyllda förhållandet mellan djur och människa som statiska kategorier slutligen kan ifrågasättas.

Förutom dessa bidrag så innehåller detta nummer även ett antal recensioner och ett porträtt av djur- och gayrättsaktivisten Maureen Duffy. Jag ber att få tacka alla medverkande i detta nummer, samt även the HumAnimal group på Centrum för genusforskning vid Uppsala universitet, Karin Lindeqvist för det fina fotot som blev framsida, Erika Söderström för snygg lay-out, samt inte minst lambda nordicas redaktion, som har låtit mig vara gästredaktör för detta nummer. 